\title{
Effect of packaging type and storage temperature on the quality characteristics of beef longissimus lumborum and triceps brachii muscles aged for extended storage postmortem
}

\author{
Amie G. Osterhout, C. Chad Carr, D. Dwain Johnson \\ Department of Animal Sciences, University of Florida, Gainesville, USA
}

Keywords:

Triceps brachii

Beef

Drybag

Dry aging

Extended aging

Article history:

Received 22.03.2019

Received in revised form 16.07.2019

Accepted 30.09.2019

Corresponding author:

C. Chad Carr

E-mail:

chadcarr@ufl.edu

DOI: $10.24263 / 2304-$

974X-2019-8-3-6

\section{Abstract}

Introduction. The purpose of the study was to quantify the impact of packaging type, storage temperature, and length of postmortem aging to consistently increase palatability and color stability of Longissimus lumborum (LL) and TBmuscles that represent the bulk of today's supply.

Materials and methods. Paired longissimus lumborum (LL) and triceps brachii (TB) muscles were selected from 27 and 54 A-maturity beef carcasses with marbling scores of Slight 50 to Small 50 at grading. One muscle from each pair was stored at 0 and $4{ }^{\circ} \mathrm{C}$, respectively, for 21,32 , or 42 days for $L L$, and 21,28 , or 35 days for $\mathrm{TB}$, in one of three packaging options; DryBag®, traditional vacuum-bag, or no bag.

Result and discussion. Saleable yields were similar forDryBag®and traditional dry agedsubprimals. Aging temperature and packaging type had little impact on any quality parameters evaluated. Steaks from LL muscles aged for 42 days had lower shear force values and more tender trained sensory panel values than steaks from LL aged for 21 days, although the actual difference was marginal. Tenderness of steaks from TB muscles was similar regardless of aging. Length of aging had more influence on saleable yields than palatability, and storage temperature and packaging had little influence on either.

Conclusion. Traits measured from subprimals aged in a DryBag® were similar to traditional dry aging. Packaging (vacuum vs. non) had a slight influence on palatability. Storage temperature $\left(0\right.$ vs. $\left.4^{\circ} \mathrm{C}\right)$ had little impact on any trait evaluated. Length of aging (21 to 42) had more influence on cutting yields than palatability 


\section{Introduction}

Tenderness has been consistently ranked as the most important aspect of a satisfactory beef eating experience by consumers (Morgan, Savell, Hale, Miller, Griffin, Cross, and Shackelford, 1991; Miller, Hoover, Cook, Guerra, Huffman, Tinney, and Huffman, 1995; Miller, Carr, Ramsey, Crockett, and Hoover, 2001). Retail cuts from the rib and loin containing the longissmusare marketed at a premium due to their potential innate tenderness; however, those from the chuck and round often are discounted because of real or perceived problems with tenderness (Belew, Brooks, McKenna, and Savell, 2003).

Postmortem aging is well recognized as a consistent method of increasing the tenderness and palatability of fresh beef (Warner and Kastner, 1992; Miller, Kerth, Wise, Lansdell, Stowell, and Ramsey, 1997; Gruber, Tatum, Scanga, Chapman, Smith, and Belk, 2006). There are two generally recognized packaging methods for postmortem aging: wet and dry (Smith, Nicholson, Nicholson, Harris, Miller, Griffin, and Savell, 2008). Dry aging refers to carcasses or subprimal cuts being held at humidity controlled refrigerated temperature without any type of protective packaging. Dry aged flavor attributes of a beefy, brown roasted flavor differ from the bloody, serumy flavors with metallic notes that can be produced with wet aging (Warren and Kastner, 1992; Campbell, Hunt, Levis, and Chambers, 2001). Wet aging is more common and refers to meat that is aged in a vacuum sealed barrier package at refrigerated temperatures. In the USA, the majority of all beef is vacuum packaged at the packer level then shipped to its destination where it can then be further wet aged or removed from its packaging and dry aged. Wet aging is more common because it will produce the desired increase in tenderness and flavor without the loss of yield and the necessary increase in expense associated with dry aging in regards to careful temperature and humidity control. A third method of aging beef has recently been introduced to the industry in an attempt to alleviate the challenges of dry aging. The use of a vacuum bag that is highly permeable to water vapor would in theory produce a product with the flavors associated with dry-aged beef while blocking oxygen to reduce off-flavors and possibly reduce yield loss (Ahnström, Seyfert, Hunt, and Johnson, 2006; DeGeer, Hunt, Bratcher, Crozier-Dodson, Johnson, and Stika, 2009; Dikeman, Orbuz, Gök, Akkaya, and Stroda, 2013; Li, Babol, Wallby, and Lundström, 2013).

Many studies have explored the effect of postmortem aging on the quality and palatability of steaks from the rib and short loin, however, most focused on products with Modest or greater marbling. Approximately 60 percent of all young fed beef slaughtered has between Slight ${ }^{50}$ and Small ${ }^{50}$ degrees of marbling (Cargill, 2011). Also, few studies have assessed the palatability of the primary muscle of the US clod or chuck, the Triceps brachii (TB; Shackelford, Wheeler, and Koohmaraie, 1995; Rhee, Wheeler, Shackelford, and Koohmaraie, 2004; King, Wheeler, Shackelford, and Koohmaraie, 2009).Although many studies agree that aging increases tenderness and palatability, they disagree on the magnitude of variation among the between dry and wet aging methods (Parrish, Boles, Rust, and Olson, 1991; Sitz, Calkins, Feuz, Umberger, and Eskridge, 2006; Laster, Smith, Nicholson, Nicholson, Miller, Griffin, and Savell, 2008).

Postmortem aging has also been reported to affect lean color stability and shelf-life of beef (Ledward, 1985; Feldhusen, Warnatz, Erdmann, and Wenzel, 1995; Tang, Faustman, Hoagland, Mancini, Seyfert, and Hunt, 2005, King, Shackelford, Kalchayanand, and Wheeler, 2012). Lean color is the most important characteristic relative to a consumer's purchasing decision of fresh beef at retail (Faustman, Cassens, Schaefer, Buege, Williams, and Scheller,1989; Faustman and Cassens, 1990). Consumers associate a youthful, cherryred, beef lean color with a safe, wholesome, and highly palatable fresh beef product. When 
consumers see product displaying a darker lean color or lean discoloration, they associate this with potentially being less than desirable relative to palatability or that the product is not safe to consume (Smith, Tatum, and Morgan, 1993). Consumers rely on color because they have no other means of assessing quality when purchasing meat.

Gruber, Tatum,Scanga, Chapman, Smith, and Belk. (2006). reported that the longissimus, was one of seventeen beef muscles that responded most to postmortem aging and was continuing to show improvements in shear force values up to 28 days postmortem, especially in lower degrees of marbling (Slight). King, Wheeler, Shackelford, and Koohmaraie(2009) reported that slight differences in aging temperature impacted tenderness and that increasing aging time from 28 to $42 \mathrm{~d}$ postmortem improved slice shear force of center-cut sirloin steaks. Researchers (Ahnström, Seyfert, Hunt, and Johnson, 2006 and DeGeer, Hunt, Bratcher, Crozier-Dodson, Johnson, and Stika, 2009) have demonstrated the effectiveness of alternative packaging methods when aging beef for extended periods of time postmortem but did not include intermediate levels of marbling nor muscles other than the longissimus in their respective studies. Individually, each of the factors (i.e. temperature, time, and packaging) have been studied to some extent. However, the combination of temperature, aging period, and storage environment have not been thoroughly evaluated, particularly not with muscles other than longissimus of product quality representing the bulk of the U.S. beef supply. The purpose of the study was to quantify the impact of packaging type, storage temperature, and length of postmortem aging to consistently increase palatability and color stability of Longissimus lumborum (LL) and TBmuscles that represent the bulk of today's supply.

\section{Materials and Methods}

\subsection{Carcass Data}

Carcasses classified as A-maturity were evaluated for marbling using the VBG 2000 gradingsystem (E+V Technology, Oranienburg, Germany). Instrument marbling scores for both sides of each carcass were required to be between Slight ${ }^{50}$ and Small ${ }^{50}$ degrees of marbling at the $12^{\text {th }} / 13^{\text {th }}$ rib interface. This approachwas consistent with normal application of officialUSDA quality grades for beef carcasses (USDA, 1997).

Paired beef LL (boneless, beef strip loin, IMPS\# 180; $\mathrm{n}=54$ ) and paired TB (boneless, beef clod heart, IMPS \# 114E; $n=108)$ were collected at 24h postmortem from 27 , or 54 commercially slaughtered A-maturity beef carcasses, respectively (Table 1).

Simple means for carcass traits from which

Table 1

the longissimus lumborum and triceps brachii were collected

\begin{tabular}{|c|c|c|}
\hline Trait & $\mathbf{L L}^{\mathbf{a}}$ & TB $^{\mathbf{a}}$ \\
\hline No. of carcasses & 27 & 54 \\
\hline Hot carcass wt., kg & $298.4 \pm 30.7$ & $319.7 \pm 45.1$ \\
\hline 12th-rib fat thickness, cm & $0.91 \pm 0.4$ & $0.80 \pm 0.3$ \\
\hline LM area, $\mathrm{cm}^{2}$ & $76.7 \pm 7.3$ & $82.6 \pm 10.8$ \\
\hline $\mathrm{USDA} \mathrm{YG}^{\mathrm{b}}$ & $2.6 \pm 0.6$ & $2.4 \pm 0.6$ \\
\hline Marbling $^{\mathrm{c}}$ & $410.5 \pm 30.1$ & $406.1 \pm 32.0$ \\
\hline
\end{tabular}

${ }^{a}$ Longissimus lumborum (LL) (IMPS\# 180; $\mathrm{n}=54$ ),

Triceps brachii $(\mathrm{TB})$ (IMPS \# 114E; $\mathrm{n}=108$ ).

${ }^{\mathrm{b}}$ Calculated according to USDA-AMS, 1997.

c300 to $399=$ Slight; 400 to $499=$ Small; 500 to $599=$ Modest. 


\section{Food Technology}

Samples were vacuum sealed and shipped under refrigeration to the University of Florida Meat Processing Center.

\subsection{Temperature Variation}

All LL and TB muscles were trimmed to no more than $0.64 \mathrm{~cm}$ external fat thickness prior to further fabrication. One LL $(n=26)$, and one TB $(n=54)$ from each carcass were held at $0^{\circ} \mathrm{C}$ in a humidity $(72-85 \%)$ and temperature controlled environment. The LL and TB muscles from the opposite side of the same carcasswas held at $4^{\circ} \mathrm{C}$ in similar conditions for their respective postmortem aging period.

\subsubsection{Longissimus Lumborum}

One LLfrom one side of each carcass ( $n=27$ per temperature) was separated into three equal portions along the long axis. Within each loin, the three sections were randomly allotted to aging for 21, 32 or 42 days postmortem. Also, within each loin, the three sections were allotted to one of three packaging treatments: DryBag® (B; DryBag®, MacPak, LLC, Wayzata, MN) having a water vapor transmission rate of $2500 \mathrm{~g} / \mathrm{m}^{2} / 24 \mathrm{~h}$ at $38{ }^{\circ} \mathrm{C}$ and $50 \%$ relative humidity, Traditional vacuum-bag (V; 8600-14EL, Cryovac-Sealed Air Corporation, Duncan, SC) having a water transmission rate of $0.5-0.6 \mathrm{~g} / 64,516 \mathrm{~cm}^{2} / 24 \mathrm{~h}$ at $37.8{ }^{\circ} \mathrm{C}$ and $100 \%$ relative humidity, and No packaging (D). All LL sections were weighed before and after assigned aging times. The strip loin (LL) from both sides of 3 carcasses were used to complete the random allocation into the 18 different treatment combinations. After the assigned postmortem aging period, LL sections were fabricated into $2.54 \mathrm{~cm}$ steaks $(\mathrm{n}=3)$ for sensory, Warner-Bratzler shear force (WBSF) and color stability evaluations, respectively.

\subsubsection{Triceps Brachii}

One TB from one side of each carcass $(n=54$ per temperature) were randomly assigned to one of nine packaging $\times$ aging combinations, for each of the two storage temperatures $(0$ or $4^{\circ} \mathrm{C}$ ). Packaging treatments for TB were the same as described for LL subprimals: $\mathrm{B}, \mathrm{V}$, or $\mathrm{D}$ and were allotted to postmortem aging periods of 21,28 , or 35 days. The clod heart (TB) from both sides of 9 carcasses were used to complete the random allocation into the 18 different treatment combinations.After the assigned postmortem aging period, TB muscles were fabricated into $2.54 \mathrm{~cm}$ steaks, the most medial steaks $(\mathrm{n}=3)$ were allocated to sensory, WBSF and color stability evaluations.

\subsection{Saleable yield and steak processing}

For saleable yield, all LL sections and TB muscles were weighed before and after the assigned aging periods. After aging, all muscles were trimmed to $0.25 \mathrm{~cm}$ external fat and dry and discolored portions of D and B muscles were removed. Saleable yield was reported as the weight of the non-discolored steak and lean trim divided by the section or muscles initial pre-aged weight $\times 100$.Steaks for color stability were individually placed on a Styrofoam tray containing a Dri-Loc $40 \mathrm{~g}$ white meat pad (Sealed-Air Corporation, Elmwood Park, NJ) and overwrapped with polyvinylchloride film $\left(23,250 \mathrm{~mL}\right.$ of $\mathrm{O}^{2} / \mathrm{m} 2 / 24 \mathrm{~h}{ }^{\circ} \mathrm{C} / 90 \%$ relative humidity). Sensory and WBSF steaks were vacuum sealed and frozen at $-40^{\circ} \mathrm{C}$ until analysis was completed at a later date.

\subsection{Sensory Attributes}

At $24 \mathrm{~h}$ prior to cooking, steaks were thawed at $4^{\circ} \pm 2{ }^{\circ} \mathrm{C}$. Preheated Hamilton Beach Indoor/Outdoor open top grills (Hamilton Beach Brand, Washington, NC) were used to cook steaks according to the American Meat Science Association guidelines (AMSA, 1995). Steaks were cooked to an internal temperature of $71{ }^{\circ} \mathrm{C}$, flipping once at $35{ }^{\circ} \mathrm{C}$. 


\section{Food Technology}

Thermocouples (Omega Engineering, Inc., Stanford, CT) were placed in the geometric center of each steak to constantly monitor temperature. Temperatures were recorded using 1100 Labtech Notebook for Windows 7 (Computer Boards Inc., Middleboro, MA) (Computer Boards, Inc., Middleboro, MA). The cooked steaks were sliced and served to panelist in warmed, covered containers. During sessions, panelists were randomly seated inindividual cubicles in a temperature and light controlledroom designed with positive pressure air flow. While being served, the panelists were under redfiltered lights as suggested by the American Meat ScienceAssociation (AMSA, 1995).Each panelist evaluated 4-6 samples, per session and 2 cubes per sample $\left(1.27 \mathrm{~cm}^{3}\right)$. A panel of 7-11 trained members, in accordance with the AMSA sensory guidelines, assessed each sample for 5 attributes. These evaluated sensory traits included juiciness $(1=$ extremely dry, $2=$ very dry, $3=$ moderately dry, $4=$ slightly dry, $5=$ slightly juicy, $6=$ moderately juicy, $7=$ very juicy, $8=$ extremely juicy), beef flavor intensity $(1=$ extremely bland, $2=$ very bland, $3=$ moderately bland, $4=$ slightly bland, $5=$ slightly intense, $6=$ moderately intense, $7=$ very intense, $8=$ extremely intense), overall tenderness $(1=$ extremely tough, $2=$ very tough, $3=$ moderately tough, $4=$ slightly tough, $5=$ slightly tender, $6=$ moderately tender, $7=$ very tender, $8=$ extremely tender), connective tissue (1= abundant, $2=$ moderately abundant, $3=$ slightly abundant, $4=$ moderate amount, $5=$ slight amount, $6=$ traces amount, $7=$ practically, $8=$ none detected $)$, and off-flavor $(1=$ extreme offflavor, $2=$ strong off-flavor, $3=$ moderate off-flavor, $4=$ slight off-flavor, $5=$ threshold; barely detected, $6=$ none detected).

\subsection{Warner-Bratzler Shear Force Analysis}

Steaks were cooked to the above specifications and were then chilled at $4^{\circ} \pm 2{ }^{\circ} \mathrm{C}$ for 24 h. After cooling, 6 cores, $1.27 \mathrm{~cm}$ in diameter, were removed parallel to the orientation of the muscle fibers. Each core was sheared once, perpendicular to the orientation of the muscle fibers using an Instron Universal Testing Machine (Model 1011, Instron Corporation, Canton, MA) with a Warner-Bratzler shear head at a speed of $200 \mathrm{~mm} / \mathrm{min}$.

\subsection{Color Stability}

Steaks were displayed in a Hill (Hill Refrigeration Div., Trenton, NJ) coffin-style retail case at $2 \pm 3{ }^{\circ} \mathrm{C}$ for 5 -d. Cases were illuminated with GE T8 Linear Fluorescent lamps $(2,800$ $\mathrm{lm}, 4,100 \mathrm{~K}$; General Electric Company, Fairfield, CT) that emit a case average of 1,148 lx with a 12-h on, 12-h off lighting schedule. Steaks were rotated daily to compensate for uneven temperature and light distribution within the case. Each steak was used for daily lean color evaluation. Following collection of visual data, Hunter $\mathrm{L}^{*}, \mathrm{a}^{*}$, and $\mathrm{b}^{*}$ reflectance data was collected for each steak in duplicate and averaged using a Hunter Miniscan XE Plus (Hunter Laboratory, Reston, VA) with an illuminant setting of D65/10 with a $2.54 \mathrm{~cm}$ aperture.Visual and objective color data was collected for a five day period for each cut and steak

\subsection{Statistical Analysis}

The LL muscles were analyzed as a split-plot design with the whole-plot a 2 X 3 factorial representing temperature $\mathrm{x}$ aging periods, with packaging treatment as the sub-plot. The TB muscles were analyzed as a split-plot design with the whole-plot a 2 X 3 X 3 factorial design, representing temperature $\mathrm{x}$ packaging $\mathrm{x}$ aging periods and nested within animal with subprimal as the experimental unit. 


\section{Results and Discussion}

\subsection{Saleable yield}

Vacuum packaged subprimals of both muscles had greater saleable yield percentages $(P \leq 0.05)$ than the other packaging treatments represented (Table 2). These results were expected and are consistent with several previous studies (Parrish, Boles, Rust, and Olson, 1991; Warren and Kastner, 1992; Smith, Nicholson, Nicholson, Harris, Miller, Griffin, and Savell, 2008; Laster, Smith, Nicholson, Nicholson, Miller, Griffin, and Savell, 2008). Subprimals stored in B packages did not differ from D aged subprimals for saleable yield percentage for either muscle $(P \geq 0.2)$. Previous authors were similar reporting no differences in total loss percentages between cuts stored in a highly water permeable bag and those dry aged traditionally (DeGeer, Hunt, Bratcher, Crozier-Dodson, Johnson, and Stika, 2009; Dikeman, Obuz, Gök, Akkaya, and Stroda, 2013), but contrary to findings by Ahnström, Seyfert, Hunt, and Johnson (2006) who reported meat aged in dry ageing bags for $21 \mathrm{~d}$ had a lower aging loss and trim loss than traditionally dry aged beef.

Storage temperature did not affect $(P>0.70)$ the saleable yield percentages of LLsubprimals but, TB steaks aged at $4{ }^{\circ} \mathrm{C}$ tended $(P=0.09)$ to have greater saleable yield than the same muscles stored at $0{ }^{\circ} \mathrm{C}$ (Table 2). For each muscle evaluated, the subprimals fabricated after the shortest postmortem aging period had greater saleable yield percentages $(P \leq 0.05)$ than subprimals fabricated after either of the more extended aging periods, which did not differ $(P>0.10)$. These results are consistent with previous studies stating the least amount of aging, regardless of packaging type, results in the least amount of saleable yield lost (Smith, Nicholson, Nicholson, Harris, Miller, Griffin, and Savell,, 2008; Laster, Smith, Nicholson, Nicholson, Miller, Griffin, and Savell,, 2008), and increasing postmortem aging time decreases yield and increases trim (Parrish, Boles, Rust, and Olson, 1991; Ahnström, Seyfert, Hunt, and Johnson, 2006).

Table 2

Effect of subprimal packaging type, storage temperature, and days of postmortem age on saleable yield \% of longissimus lumborum and triceps brachii muscles

\begin{tabular}{|c|c|c|c|c|c|c|c|}
\hline & \multicolumn{3}{|c|}{ Packaging $^{\mathrm{a}}$} & \multicolumn{3}{c|}{ Temperature } & \\
\hline Muscle & $\mathrm{B}$ & $\mathrm{V}$ & $\mathrm{D}$ & $\begin{array}{c}P \text { - } \\
\text { value }\end{array}$ & $4{ }^{\circ} \mathrm{C}$ & $0{ }^{\circ} \mathrm{C}$ & $P$-value \\
\hline LL & $63.8^{\mathrm{c}} 1.0$ & $79.3^{\mathrm{b} \pm} 1.0$ & $62.0^{\mathrm{c} \pm} 1.0$ & $<0.001$ & $68.1 \pm 0.8$ & $68.6 \pm 0.8$ & 0.70 \\
\hline TB & $60.5^{\mathrm{c}} \pm 1.5$ & $73.7^{\mathrm{b}} \pm 1.5$ & $60.1^{\mathrm{c}} \pm 1.5$ & 0.001 & $66.3 \pm 1.2$ & $63.3 \pm 1.3$ & 0.09 \\
\hline
\end{tabular}

\begin{tabular}{|c|c|c|c|c|c|c|}
\hline & \multicolumn{5}{|c|}{ Postmortem age } & \\
\hline Muscle & 21 & 28 & 32 & 35 & 42 & $P$-value \\
\hline LL & $72.4^{\mathrm{b}} \pm 1.4$ & - & $65.4^{\mathrm{c}} \pm 1.4$ & - & $67.2^{\mathrm{c}} \pm 1.4$ & $<0.001$ \\
\hline TB & $68.4^{\mathrm{b}} \pm 1.6$ & $63.7^{\mathrm{c}} \pm 1.6$ & - & $62.2^{\mathrm{c}} \pm 1.5$ & - & 0.01 \\
\hline
\end{tabular}

${ }^{a}$ B; DryBag ${ }^{\circledR}$, MacPak, LLC, Wayzata, MN having a water vapor transmission rate of $2500 \mathrm{~g} / \mathrm{m}^{2} / 24$ $\mathrm{h}$ at $38^{\circ} \mathrm{C}$ and $50 \%$ relative humidity, V; Traditional vacuum-bag (V; 8600-14EL, Cryovac-Sealed Air Corporation, Duncan, SC) having a water transmission rate of $0.5-0.6 \mathrm{~g} / 64,516 \mathrm{~cm}^{2} / 24 \mathrm{~h}$ at 37.8 ${ }^{\circ} \mathrm{C}$ and $100 \%$ relative humidity; D; No packaging.

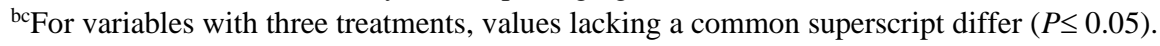




\subsection{Longissimus Lumborum}

3.2.1. Color Stability. The LL steaks aged for $42 \mathrm{~d}$ were darker, less red, and less yellow(lower $\mathrm{L}^{*}, \mathrm{a}^{*}$, and $\mathrm{b}^{*}$ values; $P \leq 0.03$ ) during the first $3 \mathrm{~d}$ of display than steaks aged for 21 and $32 \mathrm{~d}$, respectively(postmortem age $\times$ retail display day, $P<0.001$; Figure 1). As the days of retail display progressed, the steaks aged for $42 \mathrm{~d}$ became lighter (greater $\mathrm{L}^{*}$ values) while those steaks with fewer days of postmortem aging became darker (lower $\mathrm{L}^{*}$ values) during retail display (postmortem age $\times$ retail display day, $P<0.001$; Figure 1 ). Interestingly, LL steaks aged for $42 \mathrm{~d}$ were subjectively brighter (greater subjective lean color scores; $P \leq 0.03$ ) than steaks aged for 21 and $32 \mathrm{~d}$, respectively(postmortem age $\times$ retail display day, $P<0.001$; Figure 1).

The discrepancy between the greater subjective scores and objective values for the 42 $\mathrm{d}$ aged steaks is likely due to their greater percentage of surface discoloration, which due to the contrast between red and brown, potentially increased the subjective scores. Also, panelist were not able to compare steaks among aging periods concurrently, which in combination with contrast in colors, could have also increased scores of $42 \mathrm{~d}$ aged steaks. Also, previous reports have reported wet aged beef to have reduced total plate counts (Minks and Stringer, 1972) and greater retail shelf life (Miller, Davis, and Ramsey, 1993) compared to dry aged steaks, however no microbial evaluation was conducted in this study.

It is well established that consumers prefer bright, youthful beef lean color at retail (Faustman, Cassens, Schaefer, Buege, Williams, and Scheller. 1989; Faustman and Cassens, 1990; Carpenter, Cornforth, and Whittier, 2001), however, the differences in lean discoloration, though not reported, suggests that consumers would not have preferred the longer aged steaks at retail.

The LL steaks from subprimals stored in V for 32 or $42 \mathrm{~d}$ were more yellow (greater $\mathrm{b}^{*}$ values; $P \leq 0.02$ ) than steaks given $\mathrm{D}$ or $\mathrm{B}$ storage for the same aging periods (packaging type $\times$ postmortem age, $P=0.01$; Figure 2 ). Subprimal packaging type or storage temperature did not affect $(P \geq 0.39)$ the lightness of LL steaks during retail display (Table 3$)$.

Effect of subprimal packaging type and storage temperature on objective and subjective color values for the Longissimus lumborum steaks during $5 \mathrm{~d}$ of retail display

\begin{tabular}{|c|c|c|c|c|c|c|c|}
\hline & \multicolumn{4}{|c|}{ Packaging $^{\mathrm{a}}$} & \multicolumn{3}{|c|}{ Temperature } \\
\hline Trait & B & V & D & $P$-value & $4^{\circ} \mathrm{C}$ & $0^{\circ} \mathrm{C}$ & $P$-value \\
\hline $\mathrm{L} * \mathrm{~b}$ & $\begin{array}{l}32.6 \\
\pm 0.4\end{array}$ & $\begin{array}{l}33.7 \\
\pm 0.4\end{array}$ & $\begin{array}{l}32.7 \\
\pm 0.4\end{array}$ & 0.39 & $\begin{array}{l}33.0 \\
\pm 0.3\end{array}$ & $\begin{array}{l}33.0 \\
\pm 0.3\end{array}$ & 0.84 \\
\hline$a^{* b}$ & $\begin{array}{c}10.7^{\mathrm{de}} \\
\pm 0.2\end{array}$ & $\begin{array}{l}11.2^{\mathrm{d}} \\
\pm 0.2\end{array}$ & $\begin{array}{l}10.2^{\mathrm{e}} \\
\pm 0.2\end{array}$ & $<0.001$ & $\begin{array}{l}10.8 \\
\pm 0.2\end{array}$ & $\begin{array}{l}10.6 \\
\pm 0.2\end{array}$ & 0.19 \\
\hline $\begin{array}{l}\text { Subjective } \\
\text { Color }^{\mathrm{c}}\end{array}$ & $\begin{array}{l}3.9^{\mathrm{de}} \\
\pm 0.3\end{array}$ & $\begin{array}{l}4.7^{\mathrm{d}} \\
\pm 0.3\end{array}$ & $\begin{array}{l}3.8^{\mathrm{e}} \\
\pm 0.3\end{array}$ & 0.05 & $\begin{array}{c}4.2 \\
\pm 0.2\end{array}$ & $\begin{array}{c}4.1 \\
\pm 0.2\end{array}$ & 0.99 \\
\hline
\end{tabular}

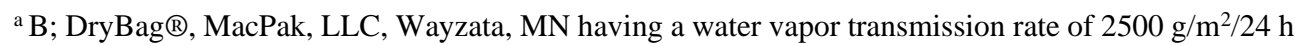
at $38{ }^{\circ} \mathrm{C}$ and $50 \%$ relative humidity; V; Traditional vacuum-bag (V; 8600-14EL, Cryovac-Sealed Air Corporation, Duncan, SC) having a water transmission rate of $0.5-0.6 \mathrm{~g} / 64,516 \mathrm{~cm}^{2} / 24 \mathrm{~h}$ at $37.8{ }^{\circ} \mathrm{C}$ and $100 \%$ relative humidity; $\mathrm{D} ;=$ No packaging.

${ }^{b} L^{*}$; measure of darkness to lightness (larger value indicates a lighter color); a*; a measure of redness (larger value indicates a redder color).

'Subjective color:1; Extremely dark red, 2; Dark red, 3; Moderately dark red, 4; Slightly dark red, 5; Slightly bright cherry red, 6; Moderately bright cherry red, 7; Bright cherry red, 8; Extremely bright cherry red.

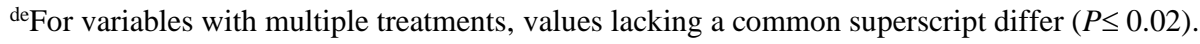


Storage temperature did not affect $(P \geq 0.19)$ rednesss or subjective color scores during retail display (Table 3). The LL steaks from subprimals aged in $\mathrm{V}$ were more red (greater $\mathrm{a}^{*}$ value; $P \leq 0.02$ ) and brighter (greater subjective lean color scores; $P \leq 0.02$ ) than steaks from subprimals aged in $\mathrm{D}$, which did not differ from subprimals aged in $\mathrm{B}$ (Table 3 ). The variation in color for steaks subprimals given B or D is likely driven by greater evaporative loss and/or greater oxidation during retail display compared with steaks from V packaged subprimals, resulting in a darker surface (Faustman and Cassens, 1990;Miller, Davis, and Ramsey, 1993).
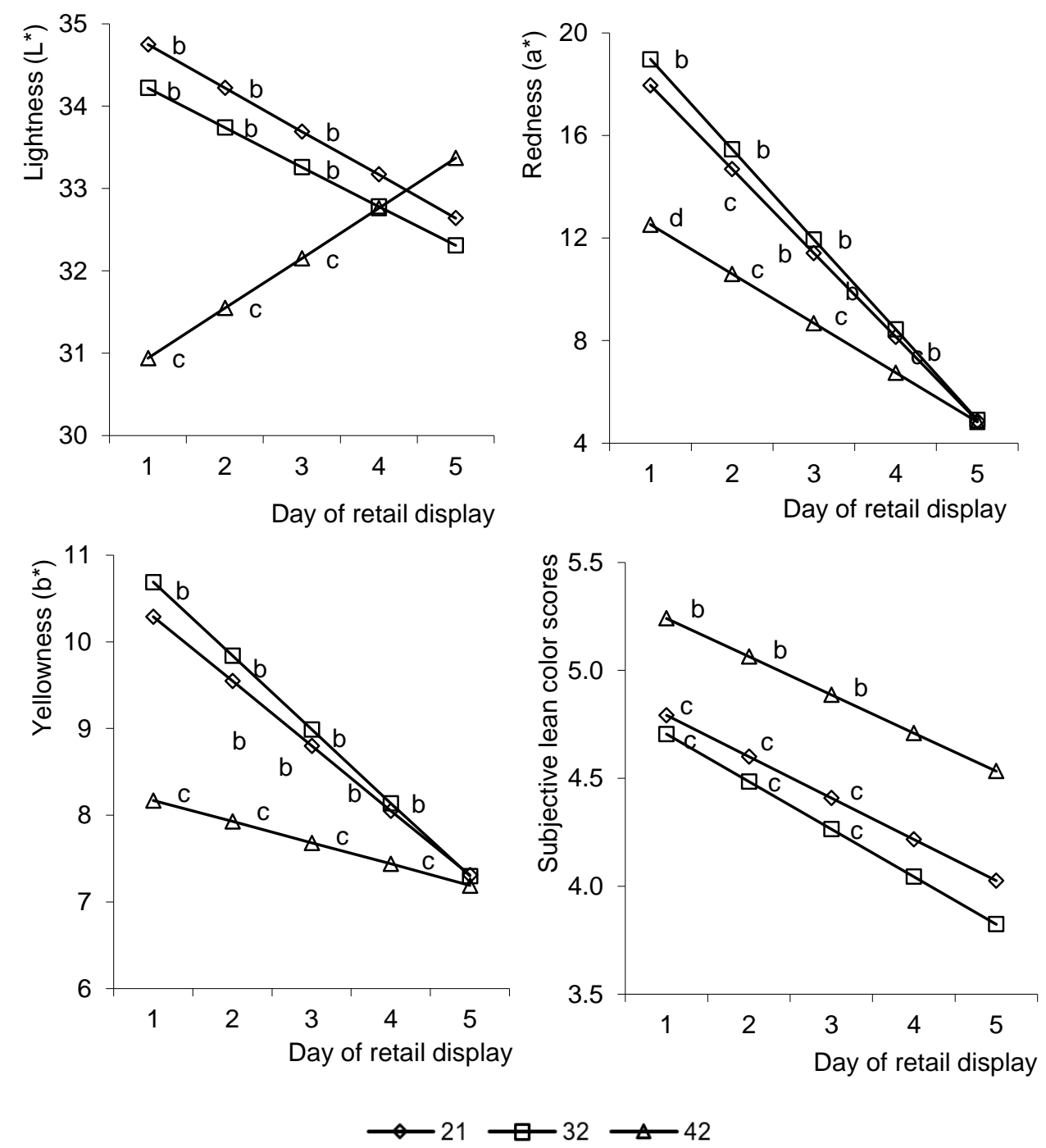

Figure 1. Interactive effect of days of postmortem age and day of retail display on lightness $\left(L^{*}\right)$ values $(P<0.001)$, redness $\left(a^{*}\right)$ values $(P<0.001)$, yellowness $\left(b^{*}\right)$ values $(P<0.001)$, and subjective lean color scores ${ }^{\mathrm{a}}(P=0.06)$ of longissmus lumborum steaks. Values within day of retail display lacking common letters differ $(P \leq 0.03)$.

${ }^{\mathrm{a}} 1$ = Extremely dark red, $2=$ Dark red, $3=$ Moderately dark red, $4=$ Slightly dark red, $5=$ Slightly bright cherry red, $6=$ Moderately bright cherry red, $7=$ Bright cherry red, $8=$ Extremely bright cherry red. 


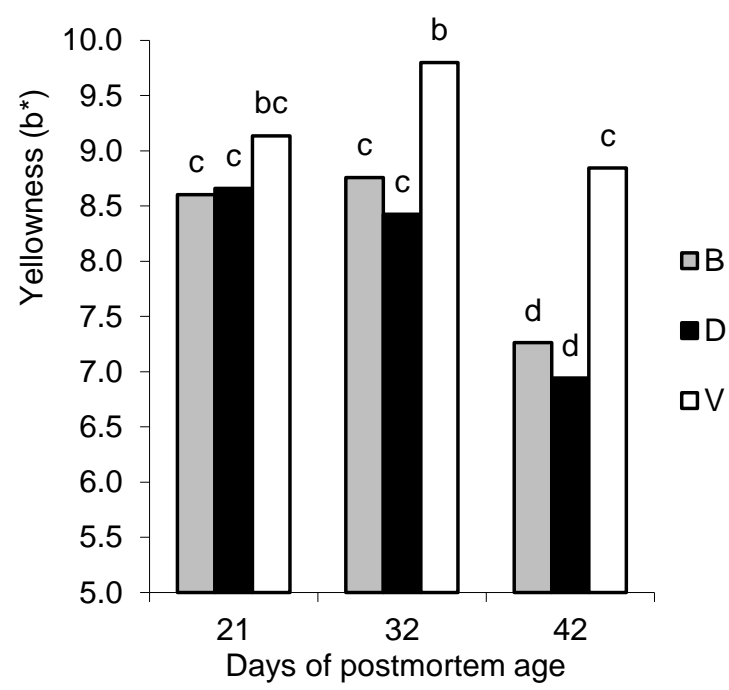

Figure 2. Interactive effect of subprimal packaging type and days of postmortem age on yellowness $\left(b^{*}\right)$ values $(P=0.01)$ of longissimus lumborum steaks.

Values with different letters differ $(P \leq 0.02)$.

${ }^{\mathrm{a}}=\mathrm{B}$; DryBag, MacPak, LLC, Wayzata, MN having a water vapor transmission rate of $2500 \mathrm{~g} / \mathrm{m}^{2} / 24$ $\mathrm{h}$ at $38^{\circ} \mathrm{C}$ and $50 \%$ relative humidity, $\mathrm{D}=$ No packaging; $\mathrm{V}=$ Traditional vacuum-bag $(\mathrm{V} ; 8600$ 14EL, Cryovac-Sealed Air Corporation, Duncan, SC) having a water transmission rate of 0.5-0.6 $\mathrm{g} / 64,516 \mathrm{~cm}^{2} / 24 \mathrm{~h}$ at $37.8{ }^{\circ} \mathrm{C}$ and $100 \%$ relative humidity.

3.2.2. Warner-Bratzler Shear Force and Trained Sensory Panel. The LL steaks from subprimals aged for $42 \mathrm{~d}$ had lower $(P \leq 0.01)$ WBSF values than steaks from subprimals aged for 21 or $32 \mathrm{~d}$ (Table 4). It is well documented that aging increases beef tenderness (Bate-Smith, 1948; Smith, Culp, and Carpenter,1978; Calkins and Seideman, 1988), complementing the decrease in WBSF values of steaks aged for 42 vs. 21 d. However, the findings for steaks aged for $32 \mathrm{~d}$ to have greater $(P \leq 0.01)$ WBSF values than the same steaks aged for $21 \mathrm{~d}$ (Table 4),is possibly an artifact of the data, and defies explanation.

Subprimal packaging type or storage temperature did not affect $(P \geq 0.15)$ WBSF values, or trained sensory panel values for juiciness or connective tissue of LL steaks (Table 4). Trained sensory panelist found LL steaks from muscles aged for $42 \mathrm{~d}$ were more tender $(P \leq 0.01)$ than steaks aged for 21 days (Table 4$)$, complementing the results for WBSF. However, the average value from all steaks would be described as "slightly tender". This is similar to Sitz, Calkins, Feuz, Umberger, and Eskridge (2006) who found no significant difference between dry- and wet-aged strip loins for flavor, juiciness, or overall acceptability.

Steaks from subprimals given D packaging had more off-flavors $(P \leq 0.01)$ than steaks that had been aged in $\mathrm{V}$ packaging, which did not differ from steaks from $\mathrm{B}$ packages (Table 4). However, it should be noted that the mean value of the off-flavor of steaks from all three packaging treatment is described as "threshold, barely detected". The primary reason for processors to $\mathrm{D}$ age beef is to impart a different flavor compared to $\mathrm{V}$ packaged beef. Numerous reports have found $\mathrm{D}$ aged beef to have a different flavor profile than $\mathrm{V}$ packaged beef (Warren and Kastner, 1992; Campbell, Hunt, Levis, and Chambers, 2001). It should be noted that despite training, members of this sensory panel were generally accustomed to the serumy and sour notes of $\mathrm{V}$ packaged beef compared to $\mathrm{D}$ aged beef, potentially rationalizing the difference in off-flavors. 
Table 4

Effect of subprimal packaging type, storage temperature, and days of postmortem age on Warner-Bratzler shear force (WBSF) and trained sensory panel values for longissimus lumborum steaks

\begin{tabular}{|c|c|c|c|c|c|c|c|c|c|c|c|}
\hline & \multicolumn{4}{|c|}{ Packaging $^{\mathrm{a}}$} & \multicolumn{3}{|c|}{ Temperature } & \multicolumn{4}{|c|}{ Postmortem age } \\
\hline Trait & B & $\mathbf{V}$ & D & $\begin{array}{c}\mathbf{P}- \\
\text { value }\end{array}$ & $4{ }^{\circ} \mathrm{C}$ & $\mathbf{0}^{\circ} \mathbf{C}$ & P-value & 21 & 32 & 42 & $\begin{array}{c}\text { P- } \\
\text { value }\end{array}$ \\
\hline WB & \begin{tabular}{|l|}
32.7 \\
\pm 0.9
\end{tabular} & \begin{tabular}{|l|}
32.8 \\
\pm 0.9 \\
\end{tabular} & $\begin{array}{l}32.3 \\
\pm 0.9\end{array}$ & 0.92 & \begin{tabular}{|l|}
32.0 \\
\pm 0.9
\end{tabular} & \begin{tabular}{|l|}
33.3 \\
\pm 0.9 \\
\end{tabular} & 0.24 & $\begin{array}{l}31.7^{\mathrm{e}} \\
\pm 0.9\end{array}$ & $\begin{array}{l}37.5^{\mathrm{d}} \\
\pm 0.9\end{array}$ & $\begin{array}{l}28.7^{\mathrm{f}} \\
{ }^{ \pm} 0.9\end{array}$ & $<0.001$ \\
\hline Juic & $\begin{array}{c}5.2 \\
\pm 0.1\end{array}$ & \begin{tabular}{|c|}
5.1 \\
\pm 0.1
\end{tabular} & $\begin{array}{c}5.1 \\
\pm 0.1\end{array}$ & 0.59 & $\begin{array}{c}5.2 \\
\pm 0.1\end{array}$ & \begin{tabular}{|c|}
5.1 \\
\pm 0.1
\end{tabular} & 0.55 & $\begin{array}{c}5.1 \\
\pm 0.1\end{array}$ & $\begin{array}{c}5.2 \\
\pm 0.1\end{array}$ & $\begin{array}{c}5.1 \\
\pm 0.1\end{array}$ & 0.85 \\
\hline Beef $\mathrm{f}$ & \begin{tabular}{|c|}
5.6 \\
\pm 0.1 \\
\end{tabular} & \begin{tabular}{|c|}
5.4 \\
\pm 0.1 \\
\end{tabular} & \begin{tabular}{|c|}
5.4 \\
\pm 0.1 \\
\end{tabular} & 0.08 & \begin{tabular}{|c|}
5.5 \\
\pm 0.1 \\
\end{tabular} & \begin{tabular}{|c|}
5.5 \\
\pm 0.1 \\
\end{tabular} & 0.92 & \begin{tabular}{|c|}
5.5 \\
\pm 0.1 \\
\end{tabular} & $\begin{array}{c}5.4 \\
\pm 0.1 \\
\end{array}$ & $\begin{array}{c}5.5 \\
\pm 0.1 \\
\end{array}$ & 0.29 \\
\hline Tend & $\begin{array}{c}5.9 \\
\pm 0.1 \\
\end{array}$ & $\begin{array}{c}5.8 \\
\pm 0.1 \\
\end{array}$ & $\begin{array}{c}5.7 \\
\pm 0.1 \\
\end{array}$ & 0.43 & $\begin{array}{c}5.9 \\
\pm 0.1 \\
\end{array}$ & \begin{tabular}{|c|}
5.7 \\
\pm 0.1 \\
\end{tabular} & 0.08 & $\begin{array}{l}5.6^{\mathrm{e}} \\
\pm 0.1 \\
\end{array}$ & $\begin{array}{l}5.8^{\mathrm{de}} \\
\pm 0.1\end{array}$ & $\begin{array}{l}5.9^{\mathrm{d}} \\
\pm 0.1\end{array}$ & 0.04 \\
\hline b & \begin{tabular}{|c|}
6.4 \\
\pm 0.1 \\
\end{tabular} & \begin{tabular}{|c|}
6.3 \\
\pm 0.1 \\
\end{tabular} & $\begin{array}{c}6.4 \\
\pm 0.1 \\
\end{array}$ & 0.37 & \begin{tabular}{|c|}
6.4 \\
\pm 0.1 \\
\end{tabular} & \begin{tabular}{|c|}
6.3 \\
\pm 0.1 \\
\end{tabular} & 5 & \begin{tabular}{|c|}
6.3 \\
\pm 0.1 \\
\end{tabular} & $\begin{array}{c}6.3 \\
\pm 0.1 \\
\end{array}$ & $\begin{array}{c}6.5 \\
\pm 0.1 \\
\end{array}$ & 0.11 \\
\hline Off-flavor $^{\mathrm{c}}$ & $\begin{array}{l}5.5^{\mathrm{de}} \\
\pm 0.1\end{array}$ & $\begin{array}{c}5.6^{\mathrm{d}} \\
\pm 0.1 \\
\end{array}$ & $\begin{array}{l}5.3^{\mathrm{e}} \\
\pm 0.1\end{array}$ & 0.03 & \begin{tabular}{|c|}
5.4 \\
\pm 0.1 \\
\end{tabular} & \begin{tabular}{|c|}
5.5 \\
\pm 0.1 \\
\end{tabular} & 0.13 & \begin{tabular}{|c|}
5.5 \\
\pm 0.1 \\
\end{tabular} & $\begin{array}{c}5.5 \\
\pm 0.1\end{array}$ & $\begin{array}{c}5.4 \\
\pm 0.1\end{array}$ & 0.38 \\
\hline
\end{tabular}

${ }^{\text {a B }}$; DryBag, MacPak, LLC, Wayzata, MN having a water vapor transmission rate of $2500 \mathrm{~g} / \mathrm{m}^{2} / 24 \mathrm{~h}$ at $38{ }^{\circ} \mathrm{C}$ and 50\% relative humidity, V; Traditional vacuum-bag (V; 8600-14EL, Cryovac-Sealed Air Corporation, Duncan, SC) having a water transmission rate of $0.5-0.6 \mathrm{~g} / 64,516 \mathrm{~cm}^{2} / 24 \mathrm{~h}$ at $37.8{ }^{\circ} \mathrm{C}$ and $100 \%$ relative humidity; D; No packaging.

b Juiciness: 1 extremely dry, 2 very dry, 3 moderately dry, 4 slightly dry, 5 slightly juicy, 6 moderately juicy, 7 very juicy, 8 extremely juicy; Beef flavor: 1 extremely bland, 2 very bland, 3 moderately bland, 4 slightly bland, 5 slightly intense 6 moderately intense, 7 very intense 8 extremely intense; Tenderness: 1 extremely tough 2 very tough 3 moderately tough 4 slightly tough 5 slightly tender 6 moderately tender 7 very tender 8 extremely tender; Connective tissue: 1 abundant amount, 2 moderately abundant, 3 slightly abundant, 4 moderate amount, 5 slight amount, 6 traces amount, 7 practically none, 8 none detected.

${ }^{\mathrm{c}} 1$ extreme off-flavor, 2 strong off-flavor, 3 moderate off-flavor, 4 slight off-flavor, 5 threshold, barely detected, 6 none detected.

d,e,fFor variables with three treatments, values lacking a common superscript differ $(P \leq 0.01)$.

Steaks of LL stored at $4{ }^{\circ} \mathrm{C}$ tended $(P=0.08)$ to have greater sensory panel values for tenderness than those stored at $0{ }^{\circ} \mathrm{C}$ (Table 4). Postmortem aging did not affect $(P \geq 0.11)$ trained sensory panel values for juiciness, beef flavor, off-flavor or connective tissue of LL steaks (Table 4). Most researchers have reported length of postmortem aging to affect beef flavor (Spanier, Flores, McMillin, and Bidner, 1997; Gorraiz, Beriain,, Chasco, and Insausti, 2002; Yancey, Dikeman, Hachmeister, and Milliken,2005). 


\subsection{Triceps Brachii}

3.3.1. Color Stability. Collectively, all TB steaks had similar lightness values at the start of retail display, but steaks from subprimals aged for $35 \mathrm{~d}$ trended darker (decreasing $\mathrm{L}^{*}$ values) throughout display, compared with steaks from subprimals given 21 or $28 \mathrm{~d}$ of aging which trended lighter throughout retail display (postmortem age $\times$ storage temperature $\times$ retail display day, $P \leq 0.02$; Figure 3 ).

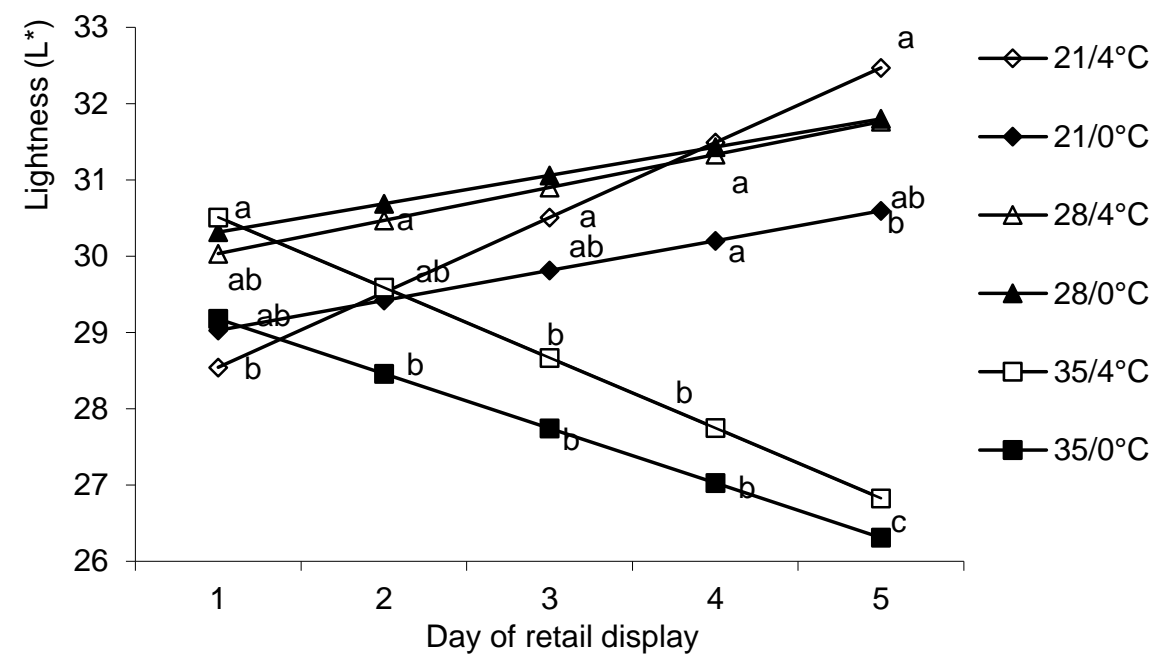

Figure 3. Interactive effect of days of postmortem age and subprimal storage temperature on lightness $\left(L^{*}\right)$ values $(P=0.02)$ of triceps brachiisteaks during $5 \mathrm{~d}$ of retail display. Values within day of retail display lacking common letters differ $(P \leq 0.024)$

Opposite to findings with the LL steaks, TB steaks from subprimals aged for $35 \mathrm{~d}$ had lower subjective color scores $(P \leq 0.03)$ than steaks from subprimals given shorter postmortem aging periods (postmortem age $\times$ retail display day, $P=0.02$; Figure 4), which were similar to results for lightness values and postmortem aging period of TB steaks during retail display. Subprimal packaging type did not affect $(P \geq 0.28)$ lightness, redness, or yellowness of TB steaks during display and subprimalstorage temperature did not affect $(P$ $\geq 0.20$ ) redness or yellowness values for TBsteaks during retail display (Table 5). The redness and yellowness values of TB steaks were lower $(P \leq 0.02)$ as length of retail display increased (Table 5). Some justification of the differences seen between the TB and LL were described by McKenna, Mies, Baird, Pfeiffer, Ellebracht, and Savell (2005) as a "very low" color stability muscle, compared to LL which was classified as a "high" color stability muscle due to differences in myoglobin content, myogobin reductase activity, and nitric oxide metmyoblobin reduction ability. 


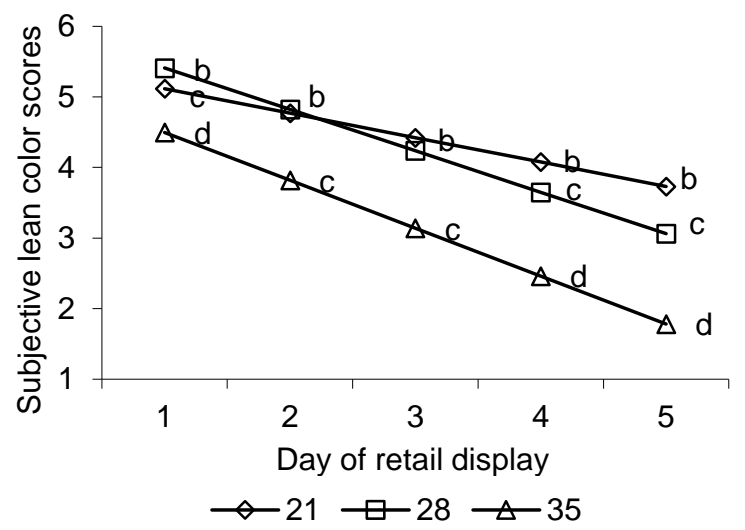

Figure 4. Interactive effect of days of postmortem age and day of retail display on subjective lean color score $^{\text {a values }}(P=0.02)$ of triceps brachiisteaks. Values within day of retail display lacking common letters differ $(P \leq \mathbf{0 . 0 3})$

${ }^{\mathrm{a}} 1=$ Extremely dark red, $2=$ Dark red, 3 = Moderately dark red, $4=$ Slightly dark red, 5 = Slightly bright cherry red, $6=$ Moderately bright cherry red, $7=$ Bright cherry red, $8=$ Extremely bright cherry red.

Table 5

Effect of subprimal packaging type, storage temperature, and days of postmortem age on objective color values for the Triceps brachii steaks during $5 \mathrm{~d}$ of retail display

\begin{tabular}{|c|c|c|c|c|c|c|c|c|c|c|c|}
\hline & \multicolumn{4}{|c|}{ Packaginga } & \multicolumn{3}{|c|}{ Temperature } & \multicolumn{4}{|c|}{ Postmortem age } \\
\hline Trait & $\mathrm{B}$ & V & $\mathrm{D}$ & $\begin{array}{c}P- \\
\text { value }\end{array}$ & $4{ }^{\circ} \mathrm{C}$ & $0{ }^{\circ} \mathrm{C}$ & $\begin{array}{l}P \text { - } \\
\text { value }\end{array}$ & 21 & 28 & 35 & $\begin{array}{l}P- \\
\text { value }\end{array}$ \\
\hline $\mathrm{L}^{* \mathrm{~b}}$ & $\begin{array}{l}29.7 \\
\pm 0.3\end{array}$ & $\begin{array}{l}30.2 \\
\pm 0.3\end{array}$ & $\begin{array}{l}29.5 \\
\pm 0.3\end{array}$ & 0.90 & -- & -- & & -- & -- & -- & \\
\hline $\mathrm{a}^{* \mathrm{~b}}$ & $\begin{array}{l}19.1 \\
\pm 0.3\end{array}$ & $\begin{array}{l}18.9 \\
\pm 0.3\end{array}$ & \begin{tabular}{|l|}
18.6 \\
\pm 0.3
\end{tabular} & 0.28 & $\begin{array}{l}18.8 \\
\pm 0.2\end{array}$ & $\begin{array}{l}18.9 \\
\pm 0.2\end{array}$ & 0.57 & $\begin{array}{l}14.5^{\mathrm{c}} \\
\pm 0.2\end{array}$ & $\begin{array}{l}12.9^{\mathrm{d}} \\
\pm 0.2\end{array}$ & $\begin{array}{l}10.3^{\mathrm{e}} \\
\pm 0.2\end{array}$ & $<0.001$ \\
\hline $\mathrm{b}^{* \mathrm{~b}}$ & $\begin{array}{l}10.9 \\
\pm 0.1\end{array}$ & $\begin{array}{l}10.1 \\
\pm 0.2\end{array}$ & \begin{tabular}{|l|}
10.9 \\
\pm 0.1
\end{tabular} & 0.57 & $\begin{array}{l}10.9 \\
\pm 0.1\end{array}$ & $\begin{array}{l}11.1 \\
\pm 0.1\end{array}$ & 0.20 & $\begin{array}{c}9.9^{c} \\
\pm 0.1\end{array}$ & $\begin{array}{l}9.6^{\mathrm{d}} \\
\pm 0.1\end{array}$ & $\begin{array}{c}8.6^{\mathrm{e}} \\
\pm 0.1\end{array}$ & $<0.001$ \\
\hline
\end{tabular}

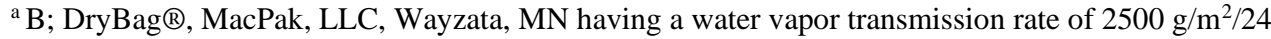
$\mathrm{h}$ at $38{ }^{\circ} \mathrm{C}$ and $50 \%$ relative humidity; V; Traditional vacuum-bag (V; 8600-14EL, Cryovac-Sealed Air Corporation, Duncan, SC) having a water transmission rate of $0.5-0.6 \mathrm{~g} / 64,516 \mathrm{~cm}^{2} / 24 \mathrm{~h}$ at 37.8 ${ }^{\circ} \mathrm{C}$ and $100 \%$ relative humidity; $\mathrm{D} ;=$ No packaging.

${ }^{b} L^{*}$; measure of darkness to lightness (larger value indicates a lighter color); $a^{*}$; a measure of redness (larger value indicates a redder color); $b^{*}$; a measure of yellowness (larger value indicates a more yellow color).

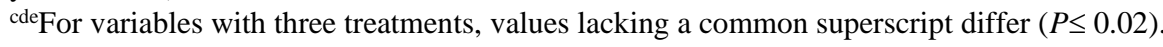

3.3.2. Warner-Bratzler Shear Force and Trained Sensory Panel. Subprimal packaging type or storage temperature did not affect $(P \geq 0.23)$ trained sensory panel values for juiciness, tenderness, connective tissue or off-flavor of TB steaks (Table 6). Additionally, subprimal packaging type did not affect $(P=0.63)$ trained sensory panel values for beef flavor, however, steaks from subprimals stored at $4{ }^{\circ} \mathrm{C}$ tended $(P=0.07)$ to have greater sensory panel values for beef flavor than steaks from subprimals stored at $0{ }^{\circ} \mathrm{C}$ (Table 6 ). Length of postmortem age did not affect $(P \geq 0.25)$ trained sensory panel values for juiciness, beef flavor, tenderness, or connective tissue of TB steaks (Table 6). Trained sensory panelist found TB steaks from muscles aged for $35 \mathrm{~d}$ to have more off-flavor $(P<0.01)$ than steaks aged for 21 or $28 \mathrm{~d}$ which did not differ (Table 6). As stated for a previous statistical 
difference in off-flavor, all three means were described as "threshold/barely detected." The authors' findings for off-flavor differed from those of King, Wheeler, Shackelford, and Koohmaraie, (2009) who reported no difference in flavor or off-flavor as aging of TB steaks increased from 7 to $42 \mathrm{~d}$.

The TB steaks from subprimals aged for $35 \mathrm{~d}$ in $\mathrm{V}$ packaging had greater $(P \leq 0.02)$ WBSF values than steaks from any other packaging type $\times$ days of postmortem aging combination (packaging type $\times$ postmortem age, $P=0.01$; Figure 5), suggesting that the subprimals which were allocated to this particular combination were innately tougher than subprimals allocated to the other combinations.

Table 6

Effect of subprimal packaging type, storage temperature, and days of postmortem age on Warner-Bratzler shear force (WBSF) and trained sensory panel values for triceps brachii steaks

\begin{tabular}{|c|c|c|c|c|c|c|c|c|c|c|c|}
\hline & \multicolumn{4}{|c|}{ Packaging $^{\mathrm{a}}$} & \multicolumn{3}{c|}{ Temperature } & \multicolumn{3}{c|}{ Postmortem age } \\
\hline Trait & $\mathrm{B}$ & $\mathrm{V}$ & $\mathrm{D}$ & $\begin{array}{c}P- \\
\text { value }\end{array}$ & $\begin{array}{c}4 \\
{ }^{\circ} \mathrm{C}\end{array}$ & $\begin{array}{c}0 \\
{ }^{\circ} \mathrm{C}\end{array}$ & $\begin{array}{c}P- \\
\text { value }\end{array}$ & 21 & 28 & 35 & $\begin{array}{c}P- \\
\text { value }\end{array}$ \\
\hline WBSF, N & -- & -- & -- & & $\begin{array}{c}39.3 \\
40.1 \\
\pm 0.1\end{array}$ & 0.69 & -- & -- & -- & \\
\hline Juiciness $^{\mathrm{b}}$ & $\begin{array}{c}5.2 \\
\pm 0.1\end{array}$ & $\begin{array}{c}5.2 \\
\pm 0.1\end{array}$ & $\begin{array}{c}5.2 \\
\pm 0.1\end{array}$ & 0.99 & $\begin{array}{c}5.2 \\
\pm 0.1\end{array}$ & $\begin{array}{c}5.2 \\
\pm 0.1\end{array}$ & 0.92 & $\begin{array}{c}5.2 \\
\pm 0.1\end{array}$ & $\begin{array}{c}5.1 \\
\pm 0.1\end{array}$ & $\begin{array}{c}5.1 \\
\pm 0.1\end{array}$ & 0.55 \\
\hline Beef flavor $^{\mathrm{b}}$ & $\begin{array}{c}5.6 \\
\pm 0.1\end{array}$ & $\begin{array}{c}5.6 \\
\pm 0.1\end{array}$ & $\begin{array}{c}5.5 \\
\pm 0.1\end{array}$ & 0.63 & $\begin{array}{c}5.6 \\
\pm 0.1\end{array}$ & $\begin{array}{c}5.5 \\
\pm 0.1\end{array}$ & 0.07 & $\begin{array}{c}5.5 \\
\pm 0.1\end{array}$ & $\begin{array}{c}5.6 \\
\pm 0.1\end{array}$ & $\begin{array}{c}5.5 \\
\pm 0.1\end{array}$ & 0.40 \\
\hline Tenderness $^{\mathrm{b}}$ & $\begin{array}{c}5.5 \\
\pm 0.1\end{array}$ & $\begin{array}{c}5.4 \\
\pm 0.1\end{array}$ & $\begin{array}{c}5.6 \\
\pm 0.1\end{array}$ & 0.23 & $\begin{array}{c}5.5 \\
\pm 0.1\end{array}$ & $\begin{array}{c}5.5 \\
\pm 0.1\end{array}$ & 0.33 & $\begin{array}{c}5.4 \\
\pm 0.1\end{array}$ & $\begin{array}{c}5.5 \\
\pm 0.1\end{array}$ & $\begin{array}{c}5.5 \\
\pm 0.1\end{array}$ & 0.46 \\
\hline Connective tissue $^{\mathrm{b}}$ & $\begin{array}{c}6.1 \\
\pm 0.1\end{array}$ & $\begin{array}{c}6.0 \\
\pm 0.1\end{array}$ & $\begin{array}{c}6.2 \\
\pm 0.1\end{array}$ & 0.24 & $\begin{array}{c}6.1 \\
\pm 0.1\end{array}$ & $\begin{array}{c}6.1 \\
\pm 0.1\end{array}$ & 0.57 & $\begin{array}{c}6.0 \\
\pm 0.1\end{array}$ & $\begin{array}{c}6.2 \\
\pm 0.1\end{array}$ & $\begin{array}{c}6.1 \\
\pm 0.1\end{array}$ & 0.25 \\
\hline Off-flavor $^{\mathrm{c}}$ & $\begin{array}{c}5.6 \\
\pm 0.1\end{array}$ & $\begin{array}{c}5.5 \\
\pm 0.1\end{array}$ & $\begin{array}{c}5.5 \\
\pm 0.1\end{array}$ & 0.69 & $\begin{array}{c}5.5 \\
\pm 0.1\end{array}$ & $\begin{array}{c}5.6 \\
\pm 0.1\end{array}$ & 0.33 & $\begin{array}{c}5.6^{\mathrm{d}} \\
\pm 0.1\end{array}$ & $\begin{array}{c}5.6^{\mathrm{d}} \\
\pm 0.1\end{array}$ & $\begin{array}{c}5.4^{\mathrm{e}} \\
\pm 0.1\end{array}$ & $<0.01$ \\
\hline
\end{tabular}

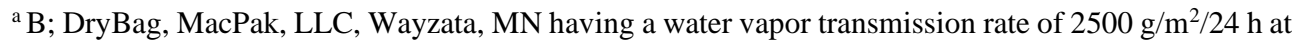
$38{ }^{\circ} \mathrm{C}$ and $50 \%$ relative humidity; V; Traditional vacuum-bag (V; 8600-14EL, Cryovac-Sealed Air Corporation, Duncan, SC) having a water transmission rate of $0.5-0.6 \mathrm{~g} / 64,516 \mathrm{~cm}^{2} / 24 \mathrm{~h}$ at $37.8{ }^{\circ} \mathrm{C}$ and $100 \%$ relative humidity; D; No packaging.

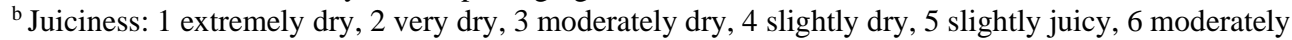
juicy, 7 very juicy, 8 extremely juicy; Beef flavor: 1 extremely bland, 2 very bland, 3 moderately bland, 4 slightly bland, 5 slightly intense 6 moderately intense, 7 very intense 8 extremely intense; Tenderness: 1 extremely tough 2 very tough 3 moderately tough 4 slightly tough 5 slightly tender 6 moderately tender 7 very tender 8 extremely tender Connective tissue: 1 abundant amount, 2 moderately abundant, 3 slightly abundant, 4 moderate amount, 5 slight amount, 6 traces amount, 7 practically none, 8 none detected.

${ }^{\mathrm{c}} 1$ extreme off-flavor, 2 strong off-flavor, 3 moderate off-flavor, 4slight off-flavor, 5 threshold; barely detected, 6 none detected.

d,e, For variables with three treatments, values lacking a common superscript differ $(P<0.001)$. 


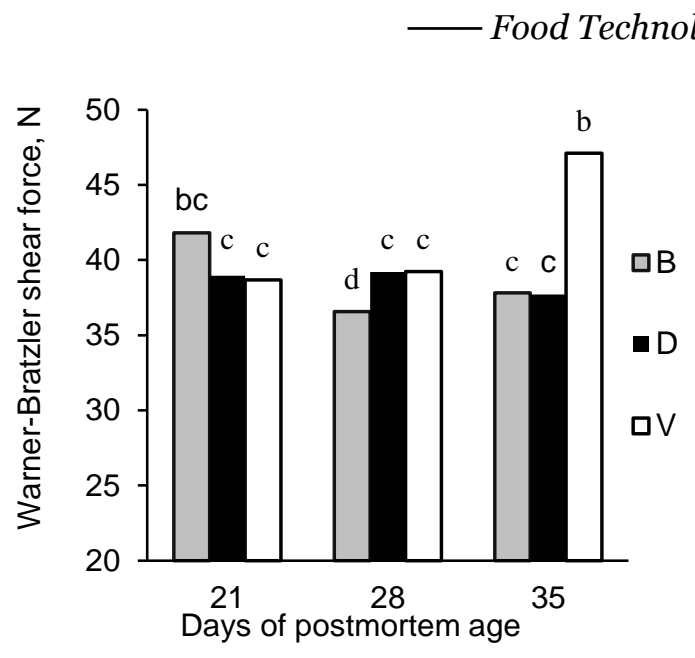

Figure 5. Interactive effect of subprimal packaging type ${ }^{\mathrm{a}}$ and days of postmortem age on Warner-

Bratzler shear force values $(P=0.01)$ of triceps brachiisteaks.Values with different letters differ $(P \leq \mathbf{0 . 0 2})$

${ }^{\mathrm{a}}=\mathrm{B}$; DryBag, MacPak, LLC, Wayzata, $\mathrm{MN}$ having a water vapor transmission rate of $2500 \mathrm{~g} / \mathrm{m}^{2} / 24 \mathrm{~h}$ at $38^{\circ} \mathrm{C}$ and $50 \%$ relative humidity, $\mathrm{V}=$ Traditional vacuum-bag (V; 8600-14EL, CryovacSealed Air Corporation, Duncan, SC) having a water transmission rate of 0.5 $0.6 \mathrm{~g} / 64,516 \mathrm{~cm}^{2} / 24 \mathrm{~h}$ at $37.8{ }^{\circ} \mathrm{C}$ and $100 \%$ relative humidity; $\mathrm{D}=\mathrm{No}$ packaging.

\section{Summary and Conclusions}

Tenderness did increase in LL steaks as the length of aging progressed, but the actual difference was marginal. Tenderness inTB steaks was similar throughout the aging process, except for the one subgroup which was speculated to simply be innately tougher. The lightness of the longest aged LLsteaks and TB steaks trended oppositely during retail display, but redness and yellowness values trended similarly for steaks from both muscles during display.All three aging methods used in our study resulted in similar palatability, but V packaged subprimals had greater saleable yield percentages than B and D packaged subprimals which were similar. Thus, V packaging will likely continue to be the preferred type of postmortem aging utilized in the U.S. beef industry.

Acknowledgement. This project was funded by the U.S. Beef Checkoff.

\section{References}

Ahnström M. L., Seyfert M., Hunt, M. C. and Johnson D. E. (2006), Dry aging of beef in a bag highly permeable to water vapour, Meat Science, 73(4), pp. 674-679.

AMSA (1995), Research guidelines for cookery, sensory evaluation, and instrumental tenderness measurement of fresh meat, Centennial, CO: American Meat Science Association in cooperation with the National Livestock and Meat Board, now the National Cattleman's Beef Association.

Bate-Smith, E. C. (1948), The physiology and chemistry of rigor mortis, with special reference to the aging of beef, Advances in Food Research, 1(1),

Belew J.B., Brooks J.C., McKenna D.R., Savell J.W. (2003), Warner-Bratzler shear evaluations of 40 bovine muscles, Meat Science, 64, pp. 507-512.

Calkins C. R., and Seideman S. C. (1988), Relationships among calcium-dependent protease, cathepsins $\mathrm{B}$ and $\mathrm{H}$, meat tenderness and the response of muscle to aging.

Campbell R. E., Hunt M. C., Levis P. and Chambers Iv E. (2001), Dry-Aging Effects on Palatability of Beef Longissimus Muscle, Journal of Food Science, 66(2), pp. 196-199.

Cargill (2011), Personal communication, Meat Solutions Group, 1/24/2011. 


\section{Food Technology}

Carpenter C. E., Cornforth D. P., and Whittier D. (2001), Consumer preferences for beef color and packaging did not affect eating satisfaction, Meat Science, 57(4), pp. 359-363.

DeGeer S. L., Hunt M. C., Bratcher C. L., Crozier-Dodson B. A., Johnson D. E., and Stika J. F. (2009), Effects of dry aging of bone-in and boneless strip loins using two aging processes for two aging times, Meat Science, 83(4), pp. 768-774.

Dikeman M. E., Orbuz E., Gök V., Akkaya L. and Stroda S. (2013), Effects of dry, vacuum, and special bag aging; USDA quality grade; and end-point temperature on yields and eating quality of beef, Longissimus lumborum steaks, Meat Science, 94(2), pp. 228-233.

Faustman C., Cassens R. G., Schaefer D. M., Buege D. R., Williams S. N., and Scheller K. K. (1989), Improvement of pigment and lipid stability in Holstein steer beef by dietary supplementation with vitamin E. J. ,Food Sci, 54, pp. 858-862.

Faustman C. and Cassens R.G. (1990), The biochemical basis for discoloration in fresh meat: A review $J .$, Muscle Foods, 1, pp. 217-243.

Feldhusen F., Warnatz A., Erdmann R., and Wenzel S. (1995), Influence of storage time on parameters of colour stability of beef, Meat Science, 40(2), pp. 235-243.

Gorraiz C., Beriain M.J., Chasco J. and Insausti K. (2002), Effect of aging time onvolatile compounds, odor, and flavor of cooked beef from Pirenaica and Friesianbulls and heifers. J. Food Sc,. 67, pp. 916-922.

Gruber S. L., Tatum J. D., Scanga J. A., Chapman P. L., Smith G. C., and Belk K. E. (2006), Effects of postmortem aging and USDA quality grade on Warner-Bratzler shear force values of seventeen individual beef muscles, Journal of Animal Science, 84, pp. 3387-3396.

King D. A., Wheeler T. L., Shackelford S. D., and Koohmaraie M. (2009), Comparison of palatability characteristics of beef gluteus medius and triceps brachii muscles, Journal of Animal Science, 87, pp. 275-284.

King D. A., Shackelford S. D., Kalchayanand N., and Wheeler T. L. (2012), Sampling and aging effects on beef longissimus color stability measurements, Journal of animal science.

Laster M.A., Smith R. D., Nicholson K. L., Nicholson J. D. W., Miller R. K., Griffin D. B., and Savell J. W. (2008), Dry versus wet aging of beef: Retail cutting yields and consumer sensory attribute evaluations of steaks from ribeyes, strip loins, and top sirloins from two quality grade groups, Meat science, 80(3), pp. 795-804.

Ledward D. A. (1985), Post-slaughter influences on the formation of metyyoglobin in beef muscles, Meat Science, 15(3), pp. 149-171.

Li X., Babol J., Wallby, A. and Lundström K. (2013), Meat quality, microbiological status and consumer preference of beef gluteus medius aged in a dry ageing bag or vacuum, Meat Science, 95 (2), pp. 229-234.

McKenna D., Mies P., Baird B., Pfeiffer K., Ellebracht J., and Savell J.W.(2005), Biochemicaland physical factors affecting discoloration characteristics of 19 bovine muscles, Meat Science, 70, pp. 665-682.

Miller M. F., Davis G. W., and Ramsey C.B. (1993), Effect of subprimalfabrication and packaging methods on palatability and retailcase-life of loin steaks from lean beef, J. Food Sci., 58(6), pp. 1544-1546.

Miller M. F., Hoover L. C., Cook K. D., Guerra A. L., Huffman K. L., Tinney K. S., and Huffman L. M. (1995), Consumer acceptability of beef steak tenderness in the home and restaurant, Journal of Food Science, 60(5), pp. 963-965.

Miller M. F., Kerth C. R., Wise J. W., Lansdell J. L., Stowell J. E., and Ramsey C. B. (1997), Slaughter plant location, USDA quality grade, external fat thickness, and aging time effects on sensory characteristics of beef loin strip steak, Journal of animal science, 75(3), pp. 662-667.

Miller M. F., Carr M. A., Ramsey C. B., Crockett K. L., and Hoover L. C. (2001), Consumer thresholds for establishing the value of beef tenderness, Journal of Animal Science, 79(12), pp. 3062-3068. 


\section{- Food Technology}

Minks D. and Stringer W. C. (1972), The influence of aging beef invacuum, J. Food Sci., 37(5), pp. 736-738.

Morgan J. B., Savell J. W., Hale D. S., Miller R. K., Griffin D. B., Cross H. R., and Shackelford S. D. (1991), National beef tenderness survey, Journal of Animal Science, pp. 69, 3274

Parrish Jr F. C., Boles J. A., Rust R. E., and Olson D. G. (1991), Dry and wet aging effects on palatability attributes of beef loin and rib steaks from three quality grade, Journal of food science, 56(3), pp. 601-603.

Rhee M. S., Wheeler T. L., Shackelford S. D., and Koohmaraie M. (2004), Variation in palatability and biochemical traits within and among eleven beef muscles, J. Anim. Sci, 82, pp. 534-550.

Shackelford S. D., Wheeler T. L., and Koohmaraie M. (1995), Relationship between shear force and trained sensory panel tenderness ratings of 10 major muscles from Bos indicus and Bos tauruscattle, J. Anim. Sci, 73, pp. 3333-3340.

Sitz B. M., Calkins C. R., Feuz D. M., Umberger W. J. and Eskridge K. M. (2006), Consumer sensory acceptance and value of wet-aged and dry-aged beef steaks, Journal of Animal Science, 84(5), pp. 1221-1226.

Smith G. C., Culp G. R., and Carpenter Z. L. (1978), Postmortem aging of beef carcasses, Journal of Food Science, 43(3), pp. 823-826.

Smith G. C., Tatum J. D., and Morgan J. B.(1993), Dark cutting beef: physiology, biochemistry, and occurrence, Colorado State University, Fort Collins.

Smith R. D., Nicholson K. L., Nicholson J. D. W., Harris K. B., Miller R. K., Griffin D. B., and Savell J. W. (2008), Dry versus wet aging of beef: Retail cutting yields and consumer palatability evaluations of steaks from US Choice and US Select short loins, Meat science, 79(4), 631-639.

Spanier A.M., Flores M., McMillin K.W. and Bidner T.D. (1997), The effectof post mortem aging on meat flavor quality in Brangus beef. Correlation oftreatments, sensory, instrumental and chemical descriptors, Food Chem, 59, pp. 531-538.

Tang J., Faustman C., Hoagland T. A., Mancini R. A., Seyfert, M., and Hunt M. C. (2005), Postmortem oxygen consumption by mitochondria and its effects on myoglobin form and stability, Journal of Agricultural and Food Chemistry, 53(4), pp. 1223-1230.

USDA, (1997), Official United States standards for grades of carcass beef, AMS, USDA, Washington, DC.

Warren K. E., and Kastner C. L. (1992), A comparison of dry-aged and vacuum-aged beef strip loins1, Journal of Muscle Foods, 3(2), pp. 151-157.

Yancey E. J., Dikeman M. E., Hachmeister K. A., Chambers E. IV., and Milliken G. A. (2005), Flavor characterization of top-blade, top-sirloin, and tenderloin steaks as affected by $\mathrm{pH}$, maturity, and marbling, Journal of Animal Science, 83, pp. 2618-2623. 